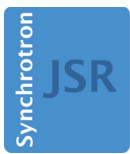

JOURNAL OF SYNCHROTRON RADIATION

ISSN 1600-5775

Received 24 July 2015

Accepted 23 September 2015

Edited by G. E. Ice, Oak Ridge National Laboratory, USA

Keywords: nuclear resonance vibrational spectroscopy; NRVS; ultra-weak signal; [NiFe] hydrogenase; $\mathrm{Ni}-\mathrm{R} ; \mathrm{Ni}-\mathrm{H}-\mathrm{Fe}$ wag mode; iron hydride.

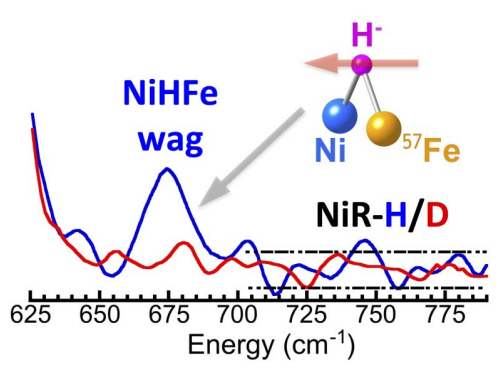

C 2015 International Union of Crystallography

\section{A strenuous experimental journey searching for spectroscopic evidence of a bridging nickel-iron-hydride in [NiFe] hydrogenase}

\author{
Hongxin Wang, ${ }^{\text {a,b* }}$ Yoshitaka Yoda, ${ }^{c}$ Hideaki Ogata, ${ }^{\text {d }}$ Yoshihito Tanaka ${ }^{c, e}$ and \\ Wolfgang Lubitz ${ }^{d}$
}

\begin{abstract}
${ }^{a}$ Department of Chemistry, University of California, 1 Cyclotron Road, Davis, CA 95616, USA, b Physical Biosciences Division, Lawrence Berkeley National Laboratory, Berkeley, CA 94720, USA, ${ }^{\mathbf{R}}$ Research and Utilization Division, SPring-8/JASRI, 1-1-1 Kouto, Sayo-cho, Sayo-gun, Hyogo 679-5198, Japan, ${ }^{\mathbf{d} M a x}$ Planck Institute for Chemical Energy Conversion, D-45470 Mülheim an der Ruhr, Germany, and ${ }^{\mathbf{e} G r a d u a t e ~ S c h o o l ~ o f ~ M a t e r i a l ~ S c i e n c e, ~ U n i v e r s i t y ~ o f ~ H y o g o, ~}$ 3-2-1 Kouto, Kamigori-cho, Ako-gun, Hyogo 678-1297, Japan. *Correspondence e-mail: hxwang2@lbl.gov
\end{abstract}

Direct spectroscopic evidence for a hydride bridge in the $\mathrm{Ni}-\mathrm{R}$ form of [NiFe] hydrogenase has been obtained using iron-specific nuclear resonance vibrational spectroscopy (NRVS). The $\mathrm{Ni}-\mathrm{H}-\mathrm{Fe}$ wag mode at $675 \mathrm{~cm}^{-1}$ is the first spectroscopic evidence for a bridging hydride in Ni-R as well as the first ironhydride-related NRVS feature observed for a biological system. Although density function theory (DFT) calculation assisted the determination of the $\mathrm{Ni}-\mathrm{R}$ structure, it did not predict the $\mathrm{Ni}-\mathrm{H}-\mathrm{Fe}$ wag mode at $\sim 675 \mathrm{~cm}^{-1}$ before NRVS. Instead, the observed $\mathrm{Ni}-\mathrm{H}-\mathrm{Fe}$ mode provided a critical reference for the DFT calculations. While the overall science about $\mathrm{Ni}-\mathrm{R}$ is presented and discussed elsewhere, this article focuses on the long and strenuous experimental journey to search for and experimentally identify the $\mathrm{Ni}-\mathrm{H}-\mathrm{Fe}$ wag mode in a $\mathrm{Ni}-\mathrm{R}$ sample. As a methodology, the results presented here will go beyond $\mathrm{Ni}-\mathrm{R}$ and hydrogenase research and will also be of interest to other scientists who use synchrotron radiation for measuring dilute samples or weak spectroscopic features.

\section{Introduction}

Molecular hydrogen $\left(\mathrm{H}_{2}\right)$ is a zero-emission energy carrier and is one of the best alternative fuels for the future, especially in urban areas with stricter environmental requirements. Hydrogenase $\left(\mathrm{H}_{2}\right.$ ase $)$ enzymes catalyze the bidirectional reaction of $2 \mathrm{H}^{+}+2 \mathrm{e}^{-} \rightleftharpoons \mathrm{H}_{2}$ (Jugder et al., 2013; Kim \& Cha, 2013) and thus have attracted interest for potential applications in $\mathrm{H}_{2}$ production in addition to their importance in biological sciences (Mertens \& Liese, 2004; Cammack et al., 2001; Heinekey, 2009; Tard \& Pickett, 2009; Yang et al., 2011; Fritsch et al., 2013; Simmons \& Artero, 2013; Matsumoto et al., 2013). While both diiron ([FeFe]) and nickel-iron ([NiFe]) $\mathrm{H}_{2}$ ases possess high catalytic activity (Evans et al., 2013; Armstrong, 2009; Shafaat et al., 2013; Lubitz et al., 2014), the latter are attractive practically since they exhibit greater $\mathrm{O}_{2}$ tolerance (Guiral et al., 2006; Evans et al., 2013; Lauterbach et al., 2015; Armstrong et al., 2009).

[NiFe] $\mathrm{H}_{2}$ ase contains several $\mathrm{Fe}-\mathrm{S}$ clusters and one $\mathrm{NiFe}$ active site, in which $\mathrm{Fe}$ is coordinated by one $\mathrm{CO}$ and two $\mathrm{CN}$ ligands (Kamali et al., 2013; Lubitz \& Ogata, 2013; Shafaat et al., 2013; Lauterbach et al., 2015). The $\mathrm{Ni}$ is coordinated to the protein matrix by four cysteinyl thiolates (S), two of which serve as bridging ligands to Fe. In addition to these two $\mathrm{S}$ ligands, there could be a third ligand to bridge the two metal atoms in several enzymatic states; for example, a hydroxide 
ligand in the oxidized inactive forms ( $\mathrm{Ni}-\mathrm{A}$ and $\mathrm{Ni}-\mathrm{B}$ ) (Dole et al., 1997; Gu et al., 2003; Gastel et al., 2005; Volbeda et al., 2015; Barilone et al., 2015) and a possible hydride (Ni-H-Fe) in the active forms $\mathrm{Ni}-\mathrm{C}$ and $\mathrm{Ni}-\mathrm{R}$ (Dole et al., 1997; Amara et al., 1999; Brecht et al., 2003; Foerster et al., 2003) (Fig. 1a). Understanding this bridging hydride will be useful in elucidating the $\mathrm{Ni}-\mathrm{R}$ structures from the proposed candidates [e.g. in Figs. $\left.1\left(b_{1}\right)-1\left(b_{6}\right)\right]$, and the possible mechanism for $\mathrm{H}_{2}$ binding and cleavage at the $\mathrm{H}_{2}$ ases' active site. For example, via a density function theory (DFT) calculation, the structures in Figs. $1\left(b_{5}\right)$ and $1\left(b_{6}\right)$ are believed to be the most likely candidates in the real Ni-R. Information about the mechanism in turn could be useful for better producing $\mathrm{H}_{2}$ in the future.

Despite progress in characterization of $\mathrm{H}_{2}$ ases by crystallography, infrared (IR) spectroscopy (Lubitz et al., 2014; Fontecilla-Camps et al., 2007; De Lacey et al., 2007) and other X-ray spectroscopies (Wang et al., 2000; Wang, Patil, Gu et al., 2001; Wang, Patil, Ralston et al., 2001), questions remain about the detailed molecular and electronic structure of various intermediates and inhibited species. These highly debated questions include the nature or even the existence of a hydride

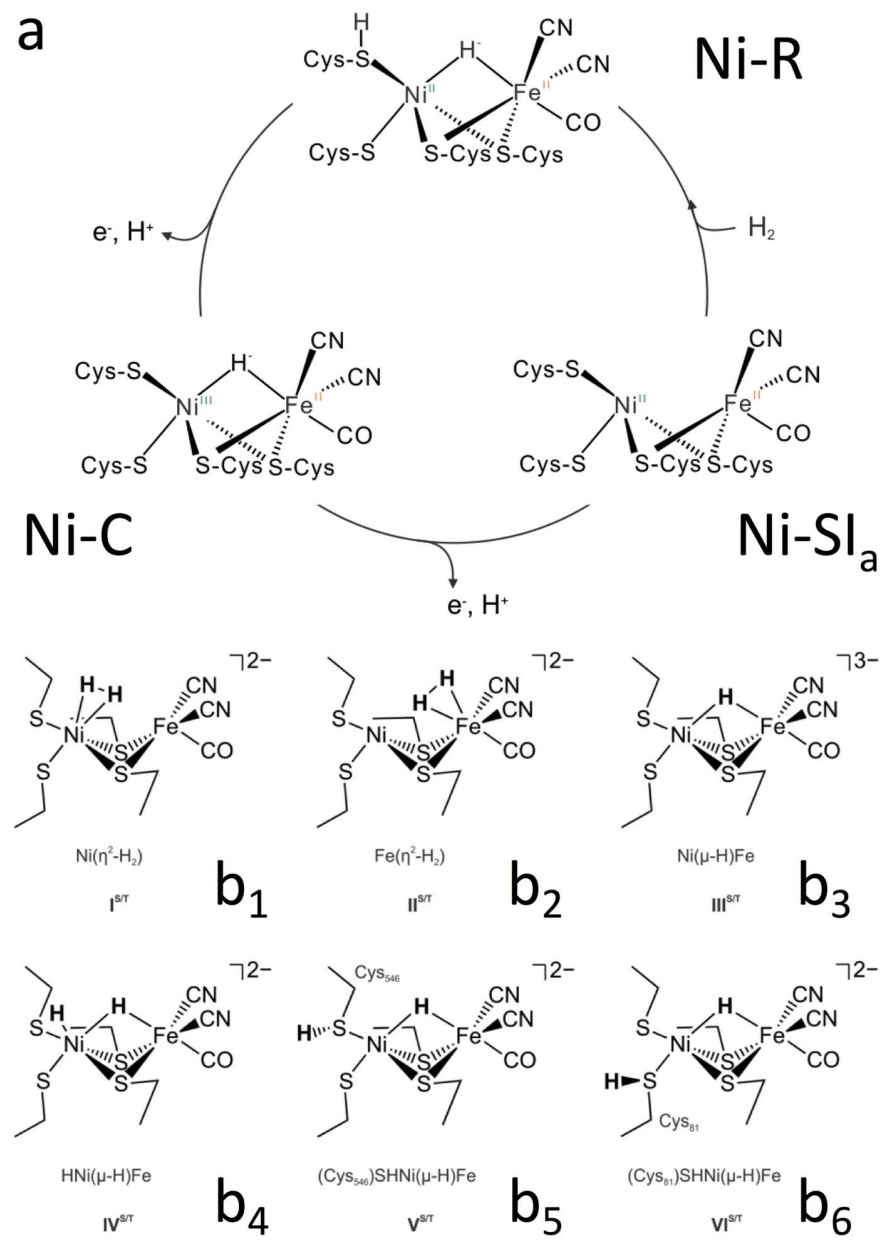

Figure 1

Schematic diagram of the [NiFe] $\mathrm{H}_{2}$ ases' catalytic cycle $(a)$ and six examples of proposed possible structures for the [NiFe] $\mathrm{H}_{2}$ ases' $\mathrm{Ni}-\mathrm{R}$ state $\left(b_{1}-b_{6}\right)$ (Ogata, Kramer et al., 2015). bridge (Ni-H-Fe) in Ni-R (Lubitz \& Ogata, 2013). Recent high-resolution crystallography demonstrated that the electron density as a hydride was detected at the bridging position between $\mathrm{Ni}$ and Fe (Ogata, Nishikawa \& Lubitz, 2015). Ni-R represents a special challenge for spectroscopic studies for a number of reasons: (i) it is EPR (electron paramagnetic resonance) silent; (ii) the Raman spectroscopy presents a problem due to its photoreactivity; and (iii) IR spectroscopy for hydride bands is extremely difficult to observe (Jayapal et al., 2008; Lubitz \& Ogata, 2013). Thus there has been no progress in traditional vibrational spectroscopy so far and the existence of $\mathrm{Ni}-\mathrm{H}-\mathrm{Fe}$ in $\mathrm{Ni}-\mathrm{R}$ is still speculation from a spectroscopic point of view. It is sometimes inferred by extrapolation from the hydride in the EPR active $\mathrm{Ni}-\mathrm{C}$ species (Brecht et al., 2003).

Nuclear resonance vibrational spectroscopy (NRVS) scans an extremely monochromatic $(\sim 1 \mathrm{meV}) \mathrm{X}$-ray beam through the nuclear resonance (at $14.4 \mathrm{keV}$ for ${ }^{57} \mathrm{Fe}$ ), and measures the corresponding creation or annihilation of phonons (Seto et al., 1995; Sturhahn et al., 1995; Yoda et al., 2001, 2012). It is a relatively new X-ray spectroscopy that became available due to the development of third-generation synchrotron sources and advanced X-ray optics. It has several distinguished advantages in comparison with traditional vibrational spectroscopic techniques such as IR and Raman spectroscopies (Smith et al., 2005; Kamali et al., 2013; Pelmenschikov et al., 2011). In the past ten years, this technique has revealed/ resolved $\mathrm{Fe}-\mathrm{S} / \mathrm{P} / \mathrm{Cl}$ and $\mathrm{Fe}-\mathrm{CO} / \mathrm{CN} / \mathrm{NO}$ vibrational modes inside various inorganic complexes and iron enzymes and has become an excellent pin-point tool in recent years to study iron-specific inorganic and bioinorganic systems (Smith et al., 2005; Xiao et al., 2005; Cramer et al., 2007; Tinberg et al., 2010; Do et al., 2011; Kamali et al., 2013). In addition, Fe-H-related NRVS features have also been resolved in several inorganic complexes (Bergmann et al., 2003; Pelmenschikov et al., 2011).

Via a series of careful and strenuous measurements, we have revealed the first direct spectroscopic evidence for $\mathrm{Ni}$ $\mathrm{H}-\mathrm{Fe}$ in a ${ }^{57} \mathrm{Fe}-$ labeled Ni-R form of Desulfovibrio vulgaris Miyazaki $\mathrm{F}$ (or $D v \mathrm{MF}$ ) [NiFe] $\mathrm{H}_{2}$ ase using ${ }^{57} \mathrm{Fe}$-specific NRVS. While its biochemical science and theoretical simulations have been presented and discussed recently (Ogata, Kramer et al., 2015), the measurement details, especially the strenuous experimental journey leading to the successful observation of the weak $\mathrm{Ni}-\mathrm{H}-\mathrm{Fe}$ wag mode, is the focus of this publication. It is not a simple or straightforward matter at all to observe the $\mathrm{Ni}-\mathrm{H}-\mathrm{Fe}$ in a $[\mathrm{NiFe}] \mathrm{H}_{2}$ ase sample, and the task will face great difficulties due to the following two aspects: (i) a $\mathrm{Fe}-\mathrm{H}$-related bending or wagging mode has a much weaker NRVS signal than $\mathrm{Fe}-\mathrm{CO}$ (Pelmenschikov et al., 2011) while $\mathrm{Fe}-\mathrm{CO}$ in $\mathrm{NiFe} \mathrm{H}_{2}$ ase is already rather weak (Kamali et al., 2013; Ogata, Kramer et al., 2015); (ii) as will be discussed in detail later, its real energy position is far from either model complexes or theoretical predictions and was virtually unknown before it was observed experimentally. This article evaluates all the matters related to whether the feature is observable, where to search for a $\mathrm{Fe}-\mathrm{H}$-related feature, whether the observation is reliable, and how the experiments 
identify the observed $675 \mathrm{~cm}^{-1}$ peak as a $\mathrm{Fe}-\mathrm{H}$-related feature.

\section{Experimental details}

The Ni-R NRVS spectra were recorded at SPring- 8 beamlines BL09XU (Yoda et al., 2001) and BL19LXU (Yabashi et al., 2001; Takahashi et al., 2001) in Japan.

\subsection{BL09XU}

BL09XU is a dedicated nuclear scattering beamline, and its instrumentation and properties have been discussed in detail elsewhere (Yoda et al., 2001). In summary, it has a Si(111) double-crystal high-heat-load monochromator (HHLM) producing $14.4 \mathrm{keV}$ radiation with $\sim 1.0 \mathrm{eV}$ resolution, followed by a high-energy-resolution monochromator (HRM) [Ge(422) $\times 2 \mathrm{Si}(975)]$ producing $14.4 \mathrm{keV}$ radiation with $0.8 \mathrm{meV}$ resolution. The beam flux was $\sim 1.4 \times 10^{9}$ photons $\mathrm{s}^{-1}$ at $0.8 \mathrm{meV}$ energy resolution. The beam size was about $0.6 \mathrm{~mm}$ (height) $\times 1 \mathrm{~mm}$ (width). BL09XU has a dedicated NRVS measurement system, including a $2 \times 2$ avalanche photodiode (APD) detector array, a set of data-acquisition electronics and a control computer with data-acquisition software.

It also has a dedicated liquid-helium (LHe) flow cryostat for measuring NRVS at a cryogenic temperature for air- or temperature-sensitive samples, such as $\mathrm{H}_{2}$ ases. The samples were maintained with $\mathrm{LHe}$ at $6-9 \mathrm{~K}$ (sensor reading). However, due to the extremely short distance from the samples' surface to the APD array, a cold-finger cryostat has to be used instead of a more efficient gas exchange cryostat (Dong et al., 2013). The real sample temperatures were much higher than 6-9 K, e.g. 50-70 K (Wang et al., 2012). This standard NRVS setup has been used in many NRVS measurements in the past and their details are discussed elsewhere (Cramer et al., 2007; Pelmenschikov et al., 2011; Wang et al., 2012, 2014).

\subsection{BL19LXU}

BL19LXU (Yabashi et al., 2001; Takahashi et al., 2001) provides the fundamental beam in the $7.2-18 \mathrm{keV}$ energy region, covering ${ }^{57} \mathrm{Fe}$ nuclear resonance at $14.4 \mathrm{keV}$. As shown in Fig. 2(a), it has a $25 \mathrm{~m}$-long undulator (Hara et al., 2002) instead of the usual $5 \mathrm{~m}$-long undulator at SPring- 8 . Therefore its HHLM provides $\sim 2.5 \times 10^{14}$ photons s $^{-1}$ at $14.4 \mathrm{keV}$, i.e. about five times higher than the beam intensity at BL09XU $\left(5 \times 10^{13}\right.$ photons s ${ }^{-1}$ after HHLM). This beamline has many advanced applications and publications over a broad area from time-resolved measurements to weak feature observations (Tanaka et al., 2011; Inada et al., 2013). It is also a good choice for NRVS measurements on weak vibrational features, which requires high beam intensity.

However, BL19LXU is not a dedicated nuclear scattering beamline and it does not have a fixed HRM and NRVS measurement station. We thus have fabricated a mobile system (Fig. 2b) which consists of a HRM, a LHe cryostat, a
$2 \times 2$ APD detector array, a rack of associated electronics, and a control computer with data-acquisition software. While these items are duplicates of those used at BL09XU, they need to be integrated into BL19LXU's experimental hutch 1 within about $36 \mathrm{~h}$ (including optimization time). Therefore, BL19LXU has similar HHLM and HRM as those at BL09XU, and provided $14.4 \mathrm{keV}$ radiation with $0.8 \mathrm{meV}$ resolution, which is suitable for NRVS measurement. The beam size was also $0.6 \mathrm{~mm}$ (height) $\times 1 \mathrm{~mm}$ (width), the same as that at BL09XU. After the HRM, a maximum $4.2 \times$ higher beam flux was recorded in comparison with that for BL09XU. However, owing to various practical limitations as well as using a movedin HRM and NRVS apparatus, the ratio in NRVS counts per second (cts/s) for the two beamlines is $2.5-3.4 \times$ instead, while for BL09XU the cts/s is stable. For example, in comparison with the BL09XU standard, the BL19LXU beam time for measuring the two Ni-R in $\mathrm{H}_{2} / \mathrm{H}_{2} \mathrm{O}$ (NiR-H for short) samples in this study has a BL19/BL09 cts/s ratio of 2.6, while that for measuring the Ni-R in $\mathrm{D}_{2} / \mathrm{D}_{2} \mathrm{O}$ (NiR-D for short) has a ratio of 3 .

\subsection{NRVS measurements}

The NRVS spectra were measured using a published procedure (Cramer et al., 2007; Seto et al., 1995; Sturhahn et al., 1995; Yoda et al., 2001), with a step size of $0.28 \mathrm{meV}$ at BL09XU and $0.27 \mathrm{meV}$ at BL19LXU. The difference is due to minor difference in energy scales for the different beamlines; the raw step sizes before the energy calibrations were both $0.295 \mathrm{meV}$. The $14.4 \mathrm{keV}$ beam with an energy resolution of $0.8 \mathrm{meV}$ was scanned through the defined energy region; the delayed nuclear fluorescence and $\mathrm{Fe} K_{\alpha}$ fluorescence from ${ }^{57} \mathrm{Fe}$ were detected with the $2 \times 2$ APD array, processed by the electronics, and stored/displayed via the control computer. The scanning region covered from $-30 \mathrm{meV}\left(-240 \mathrm{~cm}^{-1}\right)$ to $70-125 \mathrm{meV}\left(560-1000 \mathrm{~cm}^{-1}\right)$ depending on the different samples used and the different search cases.

NRVS spectral analysis was performed using the PHOENIX software package (Sturhahn et al., 1995), where the observed raw NRVS spectra (cts) were calibrated to the nuclear resonance peak position, normalized to $I_{0}$, summed and converted to the single-phonon ${ }^{57} \mathrm{Fe}$ partial vibrational density of states (PVDOS for abbreviation). The spectral conversion was optimized when the observed Stokes/antiStokes imbalance matched the imbalance calculated using the entered temperature as a parameter. The real sample temperatures were thus obtainable with the measured NRVS's Stokes/anti-Stokes imbalance (Wang et al., 2012).

The energy position for each scan was calibrated by aligning the elastic peak to zero during the NRVS spectral analysis with PHOENIX. The energy scales were usually calibrated with a standard sample of $\left[{ }^{57} \mathrm{FeCl}_{4}\right]\left[\mathrm{NEt}_{4}\right]$ with a prominent peak at $380 \mathrm{~cm}^{-1}$. It was measured inside the regular NRVS measurement chamber at cryogenic temperature. Alternatively, the energy scales can also be calibrated with ${ }^{57} \mathrm{Fe}$ metal powder at the quick-switch calibration stage at the back 


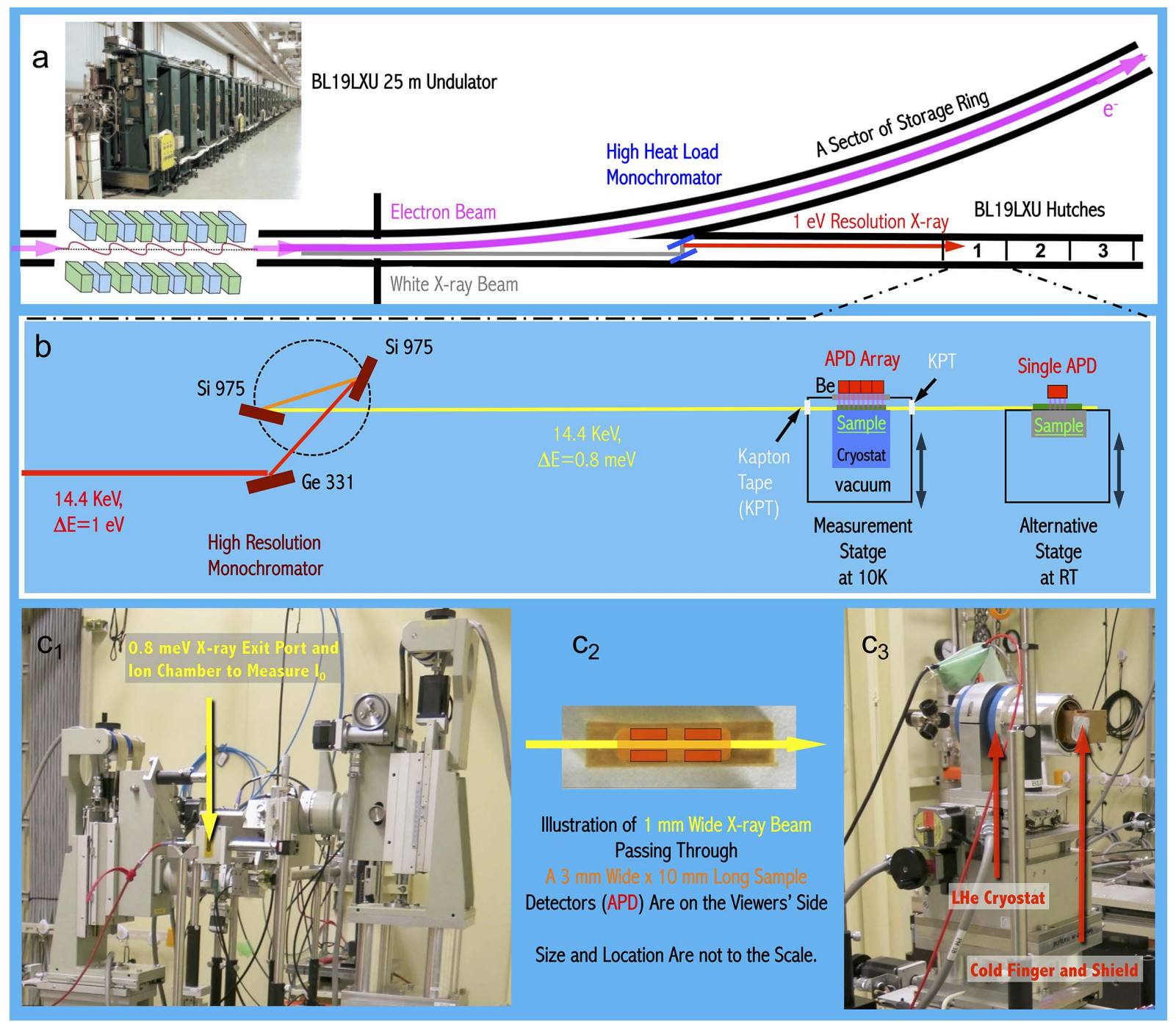

Figure 2

An illustrative diagram of BL19LXU $(a)$ and of the mobile NRVS apparatus moved into its experimental hutch $1(b)$. The top-left photograph insert shows the $25 \mathrm{~m}$-long undulator inside BL19LXU (Goto et al., 2000), and the bottom panels are (from left to right) a photograph of the HRM station ( $c_{1}$ ), an illustration of the sample/X-ray beam and APD detector positions $\left(c_{2}\right)$, and a photograph of the main NRVS measurement station $\left(c_{3}\right)$.

of the main measurement stage (Wang et al., 2013). It has a clear peak at $287 \mathrm{~cm}^{-1}$ at room temperature.

The background noise level (dark current cts/s) was estimated prior to (and sometimes during) each beam time by tuning the HRM's energy position to about $-100 \mathrm{meV}$ or about $-800 \mathrm{~cm}^{-1}$ (in reference to the resonance elastic energy), where no vibrational peak is present. The 'signal' was accumulated for either $500 \mathrm{~s}$ in total or five consecutive $100 \mathrm{~s}$ to obtain an average cts/s. For almost all the beam times, the dark current was $0.03 \mathrm{cts} / \mathrm{s}$ for our NRVS measurement system at BL09XU and at BL19LXU.

\subsection{Scan parameters}

Since the relative strength of NRVS transitions varies dramatically and since it is necessary to emphasize one region of interest (e.g. for searching for $\mathrm{Ni}-\mathrm{H}-\mathrm{Fe}$ ), the scans were divided into segments with different data collection times (seconds per point, or $\mathrm{s} / \mathrm{p}$ ). In general, $1-3 \mathrm{~s} / \mathrm{p}$ was used for the range from -240 to $400 \mathrm{~cm}^{-1}$ (covering the $\mathrm{Fe}-\mathrm{S}$ region), then $5-10 \mathrm{~s} / \mathrm{p}$ for the $\mathrm{Fe}-\mathrm{CN}$ and $\mathrm{Fe}-\mathrm{CO}$ region from 400 to $620 \mathrm{~cm}^{-1}$. A longer scanning time $(10-30 \mathrm{~s})$ was used for the candidate $\mathrm{Ni}-\mathrm{H}-\mathrm{Fe}$ searching region (e.g. at $620-770 \mathrm{~cm}^{-1}$ ). This practice is used for the NRVS measurements at both BL09XU and BL19LXU, but the exact timing for different beam times varied a little. The scan details will be discussed again in the Results and discussions section.

To compare the NRVS data from BL09XU and BL19LXU, we re-scale the BL19LXU counting time based on its maximum cts/s versus the standard maximum cts/s at BL09XU and create BL09XU equivalent seconds, e.g $10 \mathrm{~s} / \mathrm{p}$ at BL19LXU corresponds to 26 or 30 equivalent $\mathrm{s} / \mathrm{p}$ at BL09XU [corresponding to a cts/s ratio of 2.6 for measuring NiR-H and 3 for measuring NiR-D]. NiR-H was measured once at BL09XU and twice at BL19LXU with an equivalent BL09XU time of $10 \times 680=680 \mathrm{~s} / \mathrm{p}, 20 \times 24 \times 2.6=1248 \mathrm{~s} / \mathrm{p}$ and $15 \times$ $12 \times 2.6=468 \mathrm{~s} / \mathrm{p}$, respectively, in total $2396 \mathrm{~s} / \mathrm{p}$ (with a percentile of $28 \%, 52 \%$ and $20 \%$ ). NiR-D was measured three 
times at BL09XU and once at BL19LXU, equivalent to 3980 BL09XU s/p $[=(40 \times 20)+(30 \times 30)+(36 \times 30)+20 \times 20 \times$ $3=2780+400 \times 3=3980]$ in the same region. More $s / p$ was used for NiR-D because more time should be used to conclude that there is no signal than to find a weak signal.

\subsection{DvMF $\mathrm{H}_{2}$ ase $\mathrm{Ni}-\mathrm{R}$ preparation}

Cells were cultivated using a minimal medium supplemented with ${ }^{57} \mathrm{FeSO}_{4}$. Fermentation was carried out in a 101 glass fermenter under anaerobic conditions, and the [NiFe] $\mathrm{H}_{2}$ ase expressed was isolated and purified as described earlier (Ogata et al., 2005). For preparing NiR-H (NiR-D), the asisolated $[\mathrm{NiFe}] \mathrm{H}_{2}$ ase was transferred from $25 \mathrm{mM}$ Tris- $\mathrm{HCl}$ ( $\mathrm{pH}=7.4$ ) buffer to $100 \mathrm{~m} M \operatorname{MES}(\mathrm{pH}=5.0$ or $\mathrm{pD}=5.0)$ and was then purged with 1.2 bar $\mathrm{H}_{2}$ (or 1.3 bar $\mathrm{D}_{2}$ ) for more than $8 \mathrm{~h}$. The solutions were then loaded into NRVS cells under anaerobic conditions. The final $\mathrm{H}_{2}$ ase samples had a concentration of about $4 \mathrm{~m} M$.

Fourier transform IR (FTIR) spectra were recorded on a Bruker IFS66v/S FTIR spectrometer to ensure the samples were in their supposed states (Ni-R1: one of the subforms of $\mathrm{Ni}-\mathrm{R}$ ). It was measured in transmission mode in a sealed IR cell at room temperature and with a $2 \mathrm{~cm}^{-1}$ energy resolution.

\subsection{Model complexes and NRVS}

NRVS or the Fe-H/D-related bending positions for several $\mathrm{Fe}-\mathrm{H} / \mathrm{D}$-containing complexes are cited in this study. These complexes include (Bergmann et al., 2003; Pelmenschikov et al., 2011; Crossland et al., 2009; Schilter et al., 2012): (i) $\left[{ }^{57} \mathrm{FeH}(\mathrm{D})_{6}\right]\left[\mathrm{MgBr}(\text { thf })_{2}\right]_{4}$ (or $\mathrm{Fe}^{57} \mathrm{FeH}_{6} / \mathrm{D}_{6}$ for short); (ii) ${ }^{57} \mathrm{Fe}(\mathrm{H} / \mathrm{D})(\mathrm{CO})(\mathrm{dppe})_{2}$, dppe = 1,2-bis(diphenylphosphino)ethane (or H/DFeCO); (iii) trans $-\left[{ }^{57} \mathrm{Fe}(\mathrm{DMeOPrPE})_{2}-\right.$ $\left.\left(\mathrm{N}_{2}\right) \mathrm{H}\right]^{+} \quad\{\mathrm{DMeOPrPE}=$ 1,2-bis[bis(methoxypropyl)phosphino]ethane (or $\left.\mathrm{HFeN}_{2}\right)$; (iv) $\left[\left(\mu, \mathrm{k}_{2}\right.\right.$-bdt-H $)\left(\mu-\mathrm{PPh}_{2}\right)(\mu$ $\left.\mathrm{H})^{57} \mathrm{Fe}_{2}(\mathrm{CO})_{5}\right][\mathrm{OTf}]$ (or FeHFe); (v) [(dppe)Ni( $\mu$-pdt $)(\mu$ $\left.\mathrm{H})^{*} \mathrm{Fe}(\mathrm{CO})_{2}\left(\mathrm{Ph}_{3} \mathrm{P}\right)\right]^{+}\left({ }^{*}=\right.$ nature abundant, dppe $=1,2-$
$\left.\mathrm{Ph}_{2} \mathrm{PCH}_{2} \mathrm{CH}_{2} \mathrm{PPh}_{2}, \mathrm{pdt}^{2-}={ }^{-} \mathrm{SCH}_{2} \mathrm{CH}_{2} \mathrm{CH}_{2} \mathrm{~S}^{-}\right)\left(\right.$or $\left.\mathrm{NiH}^{*} \mathrm{Fe} X\right)$; (vi) $\left[(\right.$ dppe $) \mathrm{Ni}\left(\mu \text {-pdt) }(\mu-\mathrm{H} / \mathrm{D})^{57} \mathrm{Fe}(\mathrm{CO})_{3}\right]^{+}$(or $\left.\mathrm{NiH} / \mathrm{DFe}\right)$.

In addition, $\left[{ }^{57} \mathrm{FeCl}_{4}\right]\left[\mathrm{NEt}_{4}\right]$ and metal ${ }^{57} \mathrm{Fe}$ were used as calibration samples for energy scales (Smith et al., 2005; Wang et al., 2013).

\section{Results and discussion}

\subsection{Ni-R NRVS summary}

The overall NRVS spectra for $D v \mathrm{MF}$ NiR-H (blue) and NiR-D (red) are presented in Fig. 3 as an introduction for the signal levels for each vibrational feature.

The NRVS spectra include the very low energy intensities from the backbone motion, the $100-400 \mathrm{~cm}^{-1}$ peaks for $\mathrm{Fe}-\mathrm{S}$ cluster vibrations, the $420-530 \mathrm{~cm}^{-1}$ peaks for $\mathrm{Fe}-\mathrm{CN}$ modes, the $530-630 \mathrm{~cm}^{-1}$ peaks for $\mathrm{Fe}-\mathrm{CO}$ modes (Lauterbach et al., 2015; Kamali et al., 2013) and a weak but clear peak at $675 \mathrm{~cm}^{-1}$, which are assigned to the $\mathrm{Ni}-\mathrm{H}-\mathrm{Fe}$ wag mode (Ogata, Kramer et al., 2015). In Fig. 3, the top bars indicate different vibrational regions while the bottom bars illustrate the total time (s) used to measure the NiR-H (blue text) and NiR-D (red text) in each region. The blue text in the middle shows the signal level (cts/s) for each of the various signature peaks. While these middle blue numbers illustrate the signal level (cts/s) for NiR-H, both NiR-H and NiR-D have about the same signal level. As illustrated, $\mathrm{Fe}-\mathrm{CO} / \mathrm{CN}$ features have a much lower cts/s than the Fe-S features while the $\mathrm{Ni}-\mathrm{H}-\mathrm{Fe}$ has an even lower cts/s in comparison with the weak $\mathrm{Fe}-\mathrm{CN} /$ $\mathrm{CO}$ peaks. This provides readers with a basic idea of how weak the $\mathrm{Ni}-\mathrm{H}-\mathrm{Fe}$ peak in $\mathrm{Ni}-\mathrm{R}$ is.

Although a DFT calculation assisted the determination of the Ni-R structure from a dozen candidates [including the six in Figs. 1 $\left(b_{1}\right)-1\left(b_{6}\right)$ ] (Ogata, Kramer et al., 2015), the existence of $\mathrm{Ni}-\mathrm{H}-\mathrm{Fe}$ at $675 \mathrm{~cm}^{-1}$ for NiR-H (blue) and its absence for NiR-D (red) provided a critical observation reference for the DFT calculations, not the other way around. Without this

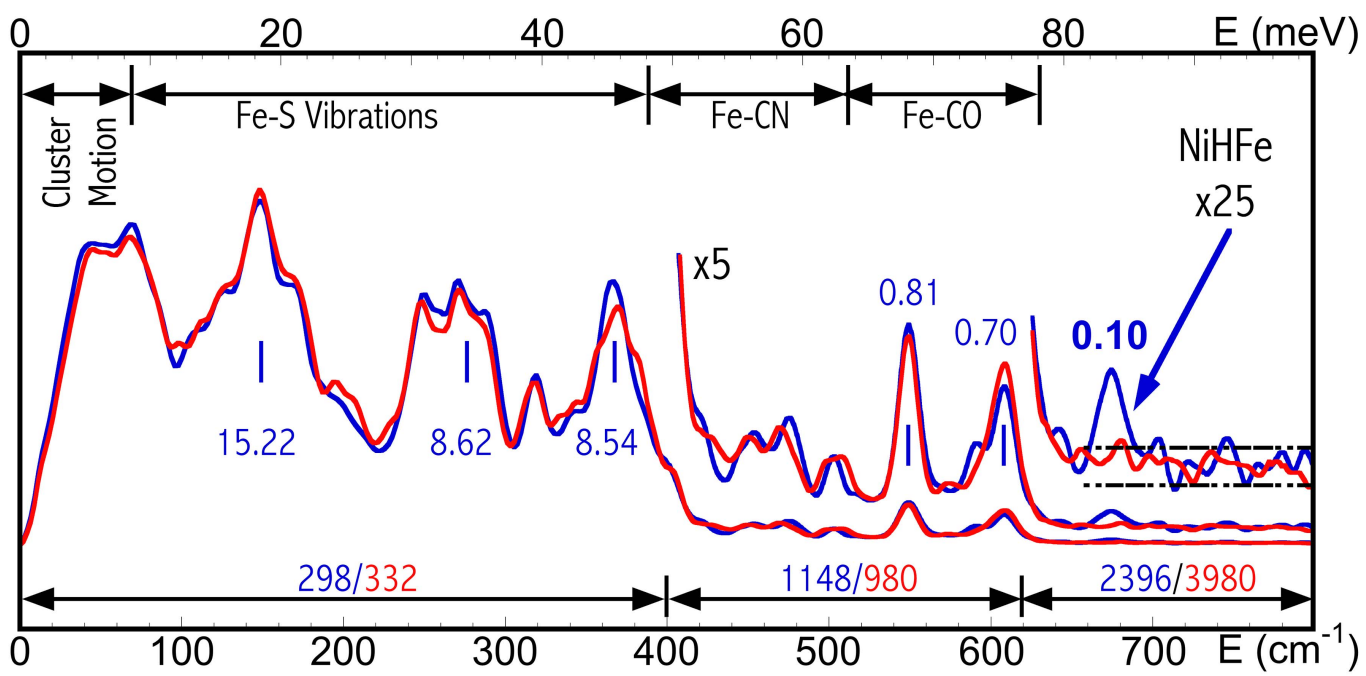

Figure 3

NRVS-derived PVDOS for $D v$ MF NiR-H (blue) and NiR-D (red) (Ogata, Kramer et al., 2015). The middle blue labels indicate the signal level (cts/s) for different vibrational features for NiR-H. The bottom labels show the total time (s) measured for each energy regions for NiR-H (blue) and NiR-D (red). 
successful observation, various DFT and normal mode analysis calculations all actually predicted $\mathrm{Ni}-\mathrm{H}-\mathrm{Fe}-$ related modes in $\mathrm{Ni}-\mathrm{R}$ at a position higher than $760 \mathrm{~cm}^{-1}$.

\subsection{Is $\mathrm{Ni}-\mathrm{H}-\mathrm{Fe}$ observable?}

It is important to first know whether the $\mathrm{Ni}-\mathrm{H}-\mathrm{Fe}$ in a $\mathrm{Ni}-\mathrm{R}$ is observable or not. As per the NRVS statistics at BL09XU between 2006 and 2010, when the HRM's energy resolution is at $0.9 \mathrm{meV}, 1 \mathrm{mM}$ of ${ }^{57} \mathrm{Fe}$ sample produced a $30 \mathrm{cts} / \mathrm{s}$ signal in the elastic peak (Wang et al., 2014). Examples of NRVS signal levels for various hypothetical $\mathrm{H}_{2}$ ase samples are illustrated in Fig. 4, using $30 \mathrm{cts} / \mathrm{s}$ per $1 \mathrm{~m} M{ }^{57} \mathrm{Fe}$. The first two columns describe vibrational feature names and their vibrational energy positions, and the third column presents the NRVS

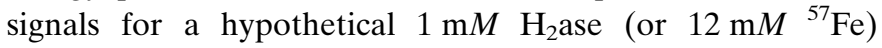
sample, which is similar to the $\mathrm{H}_{2}$ ase measured in the past (Kamali et al., 2013). It has $360 \mathrm{cts} / \mathrm{s}$ in the resonance peak, $0.7-1.2 \mathrm{cts} / \mathrm{s}$ for the $\mathrm{Fe}-\mathrm{S}$ peaks (at $150-380 \mathrm{~cm}^{-1}$ ), and $0.06 \mathrm{cts} / \mathrm{s}$ signal for $\mathrm{Fe}-\mathrm{CO}$ (at $600 \mathrm{~cm}^{-1}$ ). It is worthwhile mentioning that the then weak $\mathrm{Fe}-\mathrm{CO}$ features were

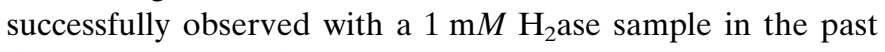
(Kamali et al., 2013).

On the other hand, the Ni-H-Fe was too weak to be observed under previous conditions $\left(1 \mathrm{mM} \mathrm{H}_{2}\right.$ ase concentration), so we have to estimate its potential cts/s (the numbers below the ' $\downarrow$ ' in Fig. 4) based on the NRVS ratio between Ni$\mathrm{H}-\mathrm{Fe}$ and $\mathrm{Fe}-\mathrm{CO}$ in available complexes, e.g. $\sim 1 / 5$ for NiHFe (Fig. $5 b$ ). A value of $0.012 \mathrm{cts} / \mathrm{s}$ is estimated for $\mathrm{Ni}-\mathrm{H}-\mathrm{Fe}$ in $1 \mathrm{~m} M \mathrm{NiR}-\mathrm{H}$ at BL09XU; it is under the dark cts/s level $(0.03 \mathrm{cts} / \mathrm{s})$ and is not observable under the given circumstances.

Since the completion of the NRVS measurements for Kamali et al.'s publication (Kamali et al., 2013), further progress has been made to increase the potential NRVS signal level (cts/s). The major advance is the samples' concentration increasing from $\sim 1 \mathrm{~m} M$ to $\sim 4 \mathrm{~m} M$, which puts the Ni-H-Fe feature at a hypothetical level of $0.012 \times 4=0.048 \mathrm{cts} / \mathrm{s}$. Some other minor improvements also contribute to the increase of cts/s: (i) BL09XU's HRM advanced from $0.9 \mathrm{meV}$ to $0.8 \mathrm{meV}$ energy resolution with almost the same level of beam intensity, which led to an increase in peaks' cts/s [maximum $=(0.9 / 0.8)=$ $112.5 \%$ ]; (ii) due to better control of the sample temperature during the NRVS measurement (Wang et al., 2012), we are able to move the sample even closer to the APD. It is difficult to estimate the real movement of the sample position but we obtained about $10 \%$ signal level increase in cts/s due to sample position alternation while still maintaining the sample temperature below $70 \mathrm{~K}$. These two points thus mean all the NRVS peaks have $\times 1.2$ height. The estimated $\mathrm{Ni}-\mathrm{H}-\mathrm{Fe}$ is then about $0.048 \times 1.2=0.058 \mathrm{cts} / \mathrm{s}$, which is comparable with the $\mathrm{Fe}-\mathrm{CO}$ feature for $1 \mathrm{mM} \mathrm{H_{2 }}$ ase in the previous measurement (Kamali et al., 2013) and thus becomes observable. Column 4 in Fig. 4 (not counting the narrow columns showing the arrow symbols) shows the estimated cts/s for a hypothetical $4 \mathrm{mM}$ $\mathrm{H}_{2}$ ase, which will be measured at the improved BL09XU $(\times 1.2)$.

\begin{tabular}{|c|c|c|c|c|c|c|c|c|}
\hline $\begin{array}{c}\text { Vibrational } \\
\text { Feature }\end{array}$ & $\begin{array}{c}\text { Energy } \\
\text { Pos. }\end{array}$ & $\mid \begin{array}{c}1 \mathrm{mM} \\
\mathrm{H}_{2} \text { ase } \\
\text { at BL09 }\end{array}$ & & $\begin{array}{c}4 \mathrm{mM} \\
\mathrm{H}_{2} \text { ase } \\
\text { at BL09 }\end{array}$ & & $\begin{array}{c}4 \mathrm{mM} \\
\mathrm{H}_{2} \text { ase } \\
\text { at BL19 }\end{array}$ & $\begin{array}{c}4.5 \mathrm{mM} \\
\mathrm{H}_{2} \text { ase } \\
\text { at BL09 }\end{array}$ & $\begin{array}{c}4.1 \mathrm{mM} \\
\mathrm{H}_{2} \text { ase } \\
\text { at BL19 }\end{array}$ \\
\hline & $\mathrm{cm}^{-1}$ & cts./s & & cts./s & & cts./s & cts./s & cts./s \\
\hline Resonance & 0 & 360 & $\rightarrow$ & 1728 & $\rightarrow$ & 4492 & 1701 & 4458 \\
\hline $\mathrm{S}-\mathrm{Fe}-\mathrm{S}$ (b) & 148 & 1.22 & $\rightarrow$ & 5.86 & $\rightarrow$ & 15.24 & 6.01 & 16.48 \\
\hline $\mathrm{Fe}-\mathrm{S}^{\mathrm{b}}(\mathrm{s})$ & 276 & 0.71 & $\rightarrow$ & 3.41 & $\rightarrow$ & 8.87 & 3.52 & 8.62 \\
\hline $\mathrm{Fe}-\mathrm{S}^{\mathrm{t}}(\mathrm{s})$ & 365 & 0.65 & $\rightarrow$ & 3.12 & $\rightarrow$ & 8.11 & 3.20 & 8.54 \\
\hline $\mathrm{Fe}-\mathrm{CO}(\mathrm{s})$ & 545 & 0.06 & $\rightarrow$ & 0.29 & $\rightarrow$ & 0.75 & 0.30 & 0.81 \\
\hline \multirow[t]{2}{*}{$\mathrm{Fe}-\mathrm{CO}(\mathrm{b})$} & 600 & 0.05 & $\rightarrow$ & 0.24 & $\rightarrow$ & 0.62 & 0.24 & 0.70 \\
\hline & & $\downarrow$ & & $\downarrow$ & & $\downarrow$ & & \\
\hline $\mathrm{Ni}-\mathrm{H}-\mathrm{Fe}$ (b) & 675 & 0.012 & & 0.058 & & 0.151 & 0.050 & 0.120 \\
\hline $\begin{array}{c}\text { vs. } \\
\text { Dark cts./s }\end{array}$ & --- & $<0.03$ & & $>0.03$ & & $>0.03$ & $>0.03$ & $>0.03$ \\
\hline
\end{tabular}

Figure 4

NRVS spectral signal levels for various vibrational features. The letters '(s)' and '(b)' stand for stretching and bending modes, respectively. The orange-colored columns are for hypothetical cases while the blue-colored columns are for real measurement cases. There are arrows between columns 3, 4 and 5 because columns 4 and 5 are all based on column 3 (1 $\mathrm{m} M$ at BL09).

Then, how much time is needed to reveal such a weak peak $(0.058 \mathrm{cts} / \mathrm{s})$ with a reasonable signal-to-noise ratio $(\mathrm{S} / \mathrm{N})$ ? In a previous publication (Wang et al., 2014) we have concluded that a $10 \mathrm{~m} M{ }^{57} \mathrm{Fe}$ sample has $\sim 1 \mathrm{cts} / \mathrm{s}$ in the $\mathrm{Fe}-\mathrm{S}$ region and $100 \mathrm{~s} / \mathrm{p}$ is thus enough for a $\mathrm{S} / \mathrm{N}=100^{1 / 2}=10$. Using the same principle, we estimated that $500 \mathrm{~s} / \mathrm{p}$ on $\mathrm{Ni}-\mathrm{H}-\mathrm{Fe}$ can lead to $0.058 \times 500=\sim 29$ pure cts and $\mathrm{S} / \mathrm{N}=29^{1 / 2}=\sim 5.4$. Although dark-current cts/s limits the best possible $\mathrm{S} / \mathrm{N}$, as will be discussed in detail later, an as-high-as-possible statistical $\mathrm{S} / \mathrm{N}$ is still required and thus $500 \mathrm{~s} / \mathrm{p}$ is a kind of realistic minimum time required to achieve a reasonable $\mathrm{S} / \mathrm{N}$ for a weak feature like $\mathrm{Ni}-\mathrm{H}-\mathrm{Fe}$. As a reference, the very weak $\mathrm{Fe}-\mathrm{CO}$ features

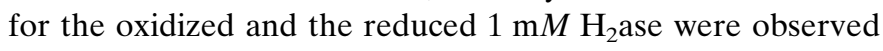
with 580 and $2180 \mathrm{~s} / \mathrm{p}$ total scanning time at BL09XU in the previous publication (Kamali et al., 2013). The $500 \mathrm{~s} / \mathrm{p}$ scanning time means, for example, $25 \times 20 \mathrm{~s} / \mathrm{p}$, leading to about $24 \mathrm{~h}$ or more beam time for one measurement with one $\mathrm{Ni}-\mathrm{H}-$ Fe search.

\subsection{Where to search For $\mathrm{Ni}-\mathrm{H}-\mathrm{Fe}$ ?}

Knowing where to search for the $\mathrm{Ni}-\mathrm{H}-\mathrm{Fe}$ signal is as important as (if not more important than) knowing it is observable. This is especially true for searching $\mathrm{Ni}-\mathrm{H}-\mathrm{Fe}$ in $\mathrm{Ni}-\mathrm{R}$, which requires long (e.g. $24 \mathrm{~h}$ or more) beam times for each search.

Since no NRVS features for iron hydrides or iron deuterides in a real iron enzyme have been published before this work, we used NRVS for a series of iron hydride/deuteride complexes and their $\mathrm{Fe}-\mathrm{H}$-related vibrational positions (Fig. 5) as a starting point to discuss the possible location of 
the $\mathrm{Ni}-\mathrm{H}-\mathrm{Fe}$ mode in Ni-R. The NRVS $\mathrm{FeH}_{6}$ (blue)/FeD 6 (red) spectra were among the first NRVS spectra obtained for chemical complexes (Bergmann et al., 2003). Their features include: the $X-\mathrm{Fe}-\mathrm{H} / X-\mathrm{Fe}-\mathrm{D}$ bending modes at $790 /$ $572 \mathrm{~cm}^{-1}$ and the Fe-D stretching at $1124 \mathrm{~cm}^{-1}$ (Fig. 5a). Later on, many other iron-hydride-containing complexes were published or evaluated, e.g. the $(\mathrm{H} / \mathrm{D}) \mathrm{FeCO}$ model complexes have the $X-\mathrm{Fe}-\mathrm{H} / X-\mathrm{Fe}-\mathrm{D}$ at $740 / 620 \mathrm{~cm}^{-1}$, respectively (Pelmenschikov et al., 2011). We noticed that the $X-\mathrm{Fe}-\mathrm{D}$ bending peak for this complex is close to the $\mathrm{Fe}-\mathrm{CO}$ peak at $560 \mathrm{~cm}^{-1}$. The NiHFe complex is used to model $[\mathrm{NiFe}] \mathrm{H}_{2}$ ases' active site and it mimics the structure for the $[\mathrm{NiFe}]$ center with very minor structural differences (Barton et al., 2009; Shafaat et al., 2012). Its $\mathrm{Ni}-\mathrm{H}-\mathrm{Fe}$ wag mode is at $758 \mathrm{~cm}^{-1}$ (Fig. $5 b$ ). Its Ni-D-Fe mode mixes into the $\mathrm{Fe}-\mathrm{CO}$ features at $550-630 \mathrm{~cm}^{-1}$ and cannot be resolved (Fig. $5 b$ ). Note that the peak at $711 \mathrm{~cm}^{-1}$ is mainly related to Ni-D stretching (mixed with $\mathrm{Fe}$ ) per DFT calculation (Ogata, Kramer et al., 2015). It is not $\mathrm{Fe}-\mathrm{D}$-related bending, which is mixed into the $\mathrm{Fe}-\mathrm{CO}$ features.

The NRVS feature most relevant to Ni-R's Ni-H-Fe is the $X-\mathrm{Fe}-\mathrm{H}$ or $\mathrm{Ni}-\mathrm{H}-\mathrm{Fe}$ feature in various complexes. The energy positions of these $\mathrm{Fe}-\mathrm{H}$-related bending modes for $\mathrm{FeH}_{6}$, $\mathrm{HFeCO}, \mathrm{HFeN}_{2}, \mathrm{FeHFe}, \mathrm{NiH}^{*} \mathrm{Fe} X$ and $\mathrm{NiHFe}$ (refer to $\$ 2$ for the full names of these complexes) are illustrated in Fig. 5 with the blue open circles between the traces in Fig. 5(a) and the traces in Fig. 5(b). The blue shaded area highlights the possible $\mathrm{Fe}-\mathrm{H}$-related bending energies while the orange (purple) area indicates the $\mathrm{Fe}-\mathrm{D}$ bending (stretching) mode regions.

From these $\mathrm{Fe}-\mathrm{H} / \mathrm{D}$ complexes we have learned the following:

(i) Although Fe-D-related bending has more intensity than $\mathrm{Fe}-\mathrm{H}$-related bending, it may mix with $\mathrm{Fe}-\mathrm{CO}$ and become unresolvable. Therefore, for Fe-CO-containing complexes, the Fe-H-related bending mode has the highest observable NRVS

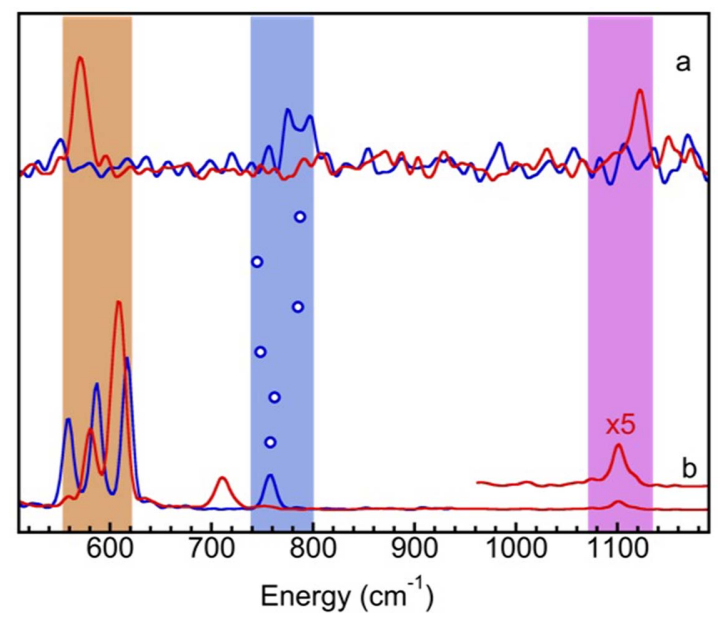

Figure 5

NRVS observed PVDOS for $(a)\left[\mathrm{FeH}_{6}\right]$ (blue)/[$\left[\mathrm{FeD}_{6}\right]$ (red); (b) NiHFe (blue)/NiDFe (red) model complexes. The blue circles indicate the Fe-Hrelated bending-mode centroids for (from top down) $\mathrm{FeH}_{6}, \mathrm{HFeCO}$, $\mathrm{HFeN}_{2}, \mathrm{FeHFe}, \mathrm{NiH}^{*} \mathrm{FeX}$ and $\mathrm{NiHFe}$, while the shaded areas are for $\mathrm{Fe}-$ D-related bending (orange), Fe-H-related bending (blue) and $\mathrm{Fe}-\mathrm{D}$ related stretching (purple). peak among all of the $\mathrm{Fe}-\mathrm{H} / \mathrm{D}$-related stretching and bending modes. It has about $1 / 4-1 / 6$ intensity in comparison with that of $\mathrm{Fe}-\mathrm{CO}$.

(ii) The $\mathrm{Fe}-\mathrm{H}-\mathrm{related}$ bending mode positions span from 740 to $790 \mathrm{~cm}^{-1}$ for the examined iron hydride complexes, including those whose spectra are not shown here. One thus should first search the $740-790 \mathrm{~cm}^{-1}$ region for the possible $\mathrm{Ni}-\mathrm{H}-\mathrm{Fe}$ mode in Ni-R. Unfortunately, several searches over an extended region of $720-840 \mathrm{~cm}^{-1}$ were unsuccessful.

DFT was also used to make a prediction about the possible position of this critical vibrational peak. However, all of the earlier DFT calculations as well as normal mode analyses (before the $\mathrm{Ni}-\mathrm{H}-\mathrm{Fe}$ was finally observed experimentally) pointed to a region with energies higher than $760 \mathrm{~cm}^{-1}$; some of them suggested a region higher (or much higher) than $800 \mathrm{~cm}^{-1}$ and we experimentally searched up to $125 \mathrm{meV}$ (or $1000 \mathrm{~cm}^{-1}$ ), but did not find anything. Each of these 'likely' $\mathrm{Ni}-\mathrm{H}-\mathrm{Fe}$ regions was searched one to two times but led to no success at all.

Although $620-720 \mathrm{~cm}^{-1}$ became the only region not searched with a great investment of beam time, the idea to search in this region was not at all popular at the time, because all the model complexes and theoretical calculations pointed to a much higher energy position. For example, the Ni-R model complex NiHFe has its Ni-H-Fe at $758 \mathrm{~cm}^{-1}, 140 \mathrm{~cm}^{-1}$ higher than its highest-energy $\mathrm{Fe}-\mathrm{CO}$ peak at $617 \mathrm{~cm}^{-1}$, while $\mathrm{Ni}-\mathrm{R}$ has a similar $\mathrm{Fe}-\mathrm{CO}$ peak position at $609 \mathrm{~cm}^{-1}$. Then the question arose: should we perform a thorough search in this unlikely but unsearched region? We did, and found the $\mathrm{Ni}-\mathrm{H}-$ Fe at $675 \mathrm{~cm}^{-1}$.

\subsection{Observing $\mathrm{Ni}-\mathrm{H}-\mathrm{Fe}$ at $675 \mathrm{~cm}^{-1}$}

As searching in the $620-720 \mathrm{~cm}^{-1}$ region was still not a mainstream opinion at that time, we first performed a balance measurement between acquiring a perfect $\mathrm{Fe}-\mathrm{CO}$ spectrum and searching for $\mathrm{Ni}-\mathrm{H}-\mathrm{Fe}$ with a $4.5 \mathrm{~m} M \mathrm{NiR}-\mathrm{H}$ sample at (improved) BL09XU. Therefore an even scanning time of $10 \mathrm{~s} / \mathrm{p}$ was used between 400 and $740 \mathrm{~cm}^{-1}$ instead of spending more time (e.g. 20-30 s) in the $\mathrm{Ni}-\mathrm{H}-\mathrm{Fe}$ region. Nevertheless, via 68 such scans (with a total scanning time of $680 \mathrm{~s} / \mathrm{p}$ ) a weak but positive peak at $675 \mathrm{~cm}^{-1}$ was observed for the first time as shown in Fig. 6(a), with the raw NRVS spectrum at the top and the converted PVDOS at the center $(\times 10)$ and the bottom ( $\times 1)$. We noticed that the $675 \mathrm{~cm}^{-1}$ energy position is much lower than any of the previous DFT or normal mode analyses 'predicted' theoretical energy positions. It is actually still at least $32 \mathrm{~cm}^{-1}$ lower than the lowest current DFT value, which is at $707 \mathrm{~cm}^{-1}$ [model VI in Fig. 1(b $\left.b_{6}\right)$ (Ogata, Kramer et al., 2015). The observed cts/s for various $\mathrm{Fe}-\mathrm{S}, \mathrm{Fe}-\mathrm{CO}$ and $\mathrm{Ni}-\mathrm{H}-$ $\mathrm{Fe}$ in Ni-R are documented in Fig. 4 [column 6 (not counting the columns showing ' $\rightarrow$ ')].

Even after this successful observation, the disputes did not disappear completely. The first argument was that the observed peak at $675 \mathrm{~cm}^{-1}$ was still too weak. The second argument attributed this peak to a Fe-CO-related feature, rather than to a Fe-H-related peak. However, there is no such 


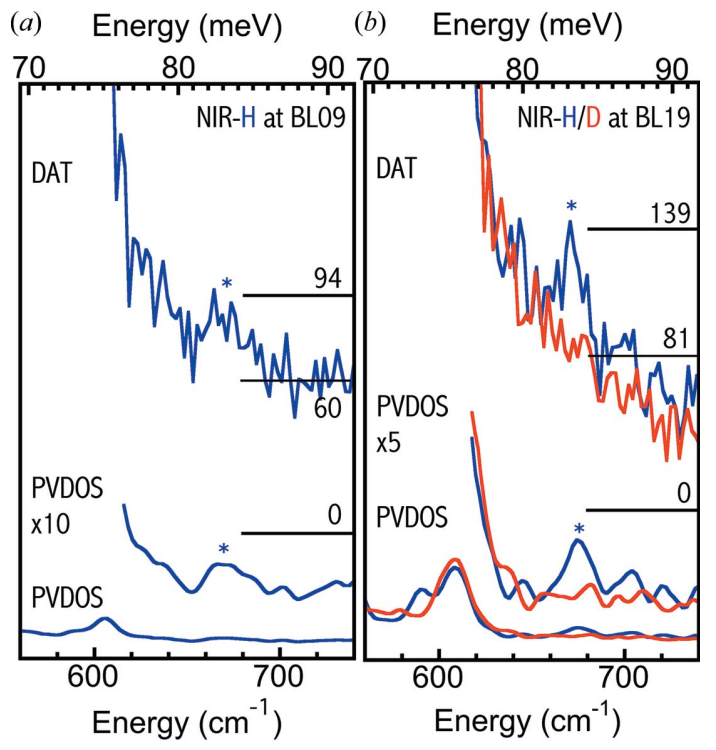

Figure 6

(a) One set (680 s/p) of raw NRVS (top) and PVDOS [bottom and middle $(\times 10)$ ] for NiR-H (blue) measured at BL09XU. (b) One set $(480 \mathrm{~s} / \mathrm{p})$ of raw NRVS (top) and the PVDOS [bottom and middle $(\times 10)$ ] for NiR-H/ D (blue/red) obtained at BL19LXU. Note that the NiR-D raw NRVS has been rescaled in order to match the NiR-H baseline (due to different measurement times).

$\mathrm{Fe}-\mathrm{CO}$ sub-feature in the mimic complex NiHFe (Ogata, Kramer et al., 2015). To clarify the second issue, we examined three NiR-D samples at BL09XU under similar experimental conditions. These NRVS measurements on NiR-D took 106 scans in total $(=40+30+36)$ and 2780 total s/p $[=(40 \times 20)+$ $(30 \times 30)+(36 \times 30)]$, but concluded no peak in the same region. This suggests that the peak at $675 \mathrm{~cm}^{-1}$ is related to a $\mathrm{Fe}-\mathrm{H}$ vibrational mode.

In order to resolve the first issue (to repeat the observation and to improve the spectral $\mathrm{S} / \mathrm{N}$ ) and to further clarify the second issue, two samples of NiR-H and one sample of NiR-D were re-measured at BL19LXU, which has a higher beam intensity and more NRVS cts/s than BL09XU. A similar pair of NRVS and PVDOS for NiR-H (blue, 24 scans, $480 \mathrm{~s} / \mathrm{p}$ ) and for NiR-D (red, 20 scans, $400 \mathrm{~s} / \mathrm{p}$ ) are compared in Fig. 6(b), illustrating much clearer evidence for the existence and the $\mathrm{Fe}-\mathrm{H}$-related nature for the $675 \mathrm{~cm}^{-1}$ peak.

\subsection{Signal levels}

From Fig. 4 (column 6 for one measurement at BL19 and column 7 for one measuremnt at BL19, not counting the columns with the arrow symbols), the observed weak $\mathrm{Ni}-\mathrm{H}-\mathrm{Fe}$ wagging mode is $27-29$ parts per million in intensity in comparison with the nuclear resonance peak, or $\sim 0.8 \%$ in comparison with the $\mathrm{Fe}-\mathrm{S}$ feature at $150 \mathrm{~cm}^{-1}$. Compared with $\mathrm{Fe}-\mathrm{CO}$ (s), this ratio is about $14.8-16.6 \%$, or, equivalently, $\mathrm{Ni}-\mathrm{H}-\mathrm{Fe}: \mathrm{Fe}-\mathrm{CO} \simeq 1: 6-1: 7$. For such a weak signal, the APD's dark-current noise (instrument error) defines the best possible $\mathrm{S} / \mathrm{N}$ because the instrumental error bar cannot be averaged lower with more signal statistics. Therefore a low $(0.03 \mathrm{cts} / \mathrm{s})$ dark current is the most important foundation for a successful observation of weak Ni-H-Fe. An estimated signal level for $\mathrm{Ni}-\mathrm{H}-\mathrm{Fe}$ for a hypothetical $4 \mathrm{~m} M \mathrm{NiR}-\mathrm{H}$ but measured at BL19LXU, which has 2.6 times more cts/s, is listed in column 5 of Fig. 4: the hypothetical $\mathrm{Ni}-\mathrm{H}-\mathrm{Fe}$ signal $=$ $\sim 0.15 \mathrm{cts} / \mathrm{s}$. The real signal level for a $4.1 \mathrm{~m} M \mathrm{NiR}-\mathrm{H}$ at BL19 is listed in column 7: $\mathrm{Ni}-\mathrm{H}-\mathrm{Fe}=0.12 \mathrm{cts} / \mathrm{s}$ for measurement 1 [and $0.13 \mathrm{cts} / \mathrm{s}$ for measurement 2 (not listed)]. In comparison with the hypothetical case (column 5), the real measurement (column 7) of Ni-H-Fe has a slightly lower cts/s level although the corresponding $\mathrm{Fe}-\mathrm{CO}$ has a higher cts/s level. This is because $\mathrm{Ni}-\mathrm{H}-\mathrm{Fe}: \mathrm{Fe}-\mathrm{CO}$ is about $1: 6$ for NiR-H (Fig. 3) as opposed to 1:4.5 for the NiHFe complex (Fig. $5 b$ ), which was used for the hyperthetical calculations.

NiR-H was measured once at BL09XU (680 s) and twice at BL19LXU $(480+180 \mathrm{~s})$. The signal level at BL09XU is estimated at $(94-60) / 680=0.05 \mathrm{cts} / \mathrm{s}$, leading to a $\mathrm{S} / \mathrm{N}=0.05 / 0.03$ $\simeq 1.7$ and a not-so-clear NRVS (Fig. $6 a$ ). Meanwhile the signal level for measurement 1 at BL19LXU (Fig. 6b) is $(139-81) /$ $480=0.12 \mathrm{cts} / \mathrm{s}$, corresponding to a $\mathrm{S} / \mathrm{N}=0.12 / 0.03=4$, a much clearer observation for the $\mathrm{Ni}-\mathrm{H}-\mathrm{Fe}$ at $675 \mathrm{~cm}^{-1}$. The signal level for measurement 2 at BL19LXU is about 0.13 and $\mathrm{S} / \mathrm{N}=$ 4.3. The total equivalent BL09XU $\mathrm{s} / \mathrm{p}$ (as defined in the experimental section) for $\mathrm{NiR}-\mathrm{H}$ in the $\mathrm{Ni}-\mathrm{Fe}-\mathrm{H}$ region is $2396 \mathrm{~s}$ and the averaged signal level is $\sim 0.1 \mathrm{cts} / \mathrm{s}$. Assuming as-high-as-possible statistics, this leads to $\mathrm{S} / \mathrm{N}=3.3$. As the real statistics are not infinite, the real $\mathrm{S} / \mathrm{N}$ is slightly lower than 3.3.

NiR-D was measured three times at BL09XU and once at BL19LXU, equivalent to $3980 \mathrm{BL09XU} \mathrm{s/p}$ in the same region (versus $2396 \mathrm{~s}$ for $\mathrm{NiR}-\mathrm{H}$ ). As there is no peak, there is no meaning to estimating the signal level or $\mathrm{S} / \mathrm{N}$ for NiR-D. However, a more equivalent $\mathrm{s} / \mathrm{p}$ was used for NiR-D because more time should be used to conclude that there is no signal than to find a weak signal.

Fig. 7 summarizes three PVDOS for NiR-H and four PVDOS for NiR-D in the region around $675 \mathrm{~cm}^{-1}$. Again, all NiR-H PVDOS show a clear peak around $675 \mathrm{~cm}^{-1}$ while none of those for NiR-D show a peak in the same region, providing solid evidence that the observed $675 \mathrm{~cm}^{-1}$ peak is real and is related to $\mathrm{Fe}-\mathrm{H}$ bending and not to a $\mathrm{Fe}-\mathrm{CO}$ feature.

\subsection{Monitoring samples' integrity}

There are several experimental conditions which make this work successful and a super-concentrated $(\sim 4 \mathrm{mM})$ and almost pure $\mathrm{Ni}-\mathrm{R}$ sample (most in $\mathrm{Ni}-\mathrm{R} 1$, a subform of $\mathrm{Ni}-\mathrm{R}$ ) is one of the most important conditions but is also difficult to realise. We proceed with exchange $\mathrm{pH}$ of the buffer $(7.4 \rightarrow$ 5.0) and with a longer period (more than $8 \mathrm{~h}$ ) of $\mathrm{H}_{2} / \mathrm{D}_{2}$ reduction. Monitoring samples' integrity can never be more important than under these circumstances. The following three steps were used to monitor the samples' integrity:

(i) NiR-H/D were first checked with FTIR at the sample preparation laboratory before sending to SPring-8 for NRVS measurements, as shown in Fig. 8(a). The Ni-R form is known to have up to three isoelectronic forms, Ni-R1, Ni-R2 and $\mathrm{Ni}-\mathrm{R} 3$. These subforms are distinguishable by FTIR and differ 


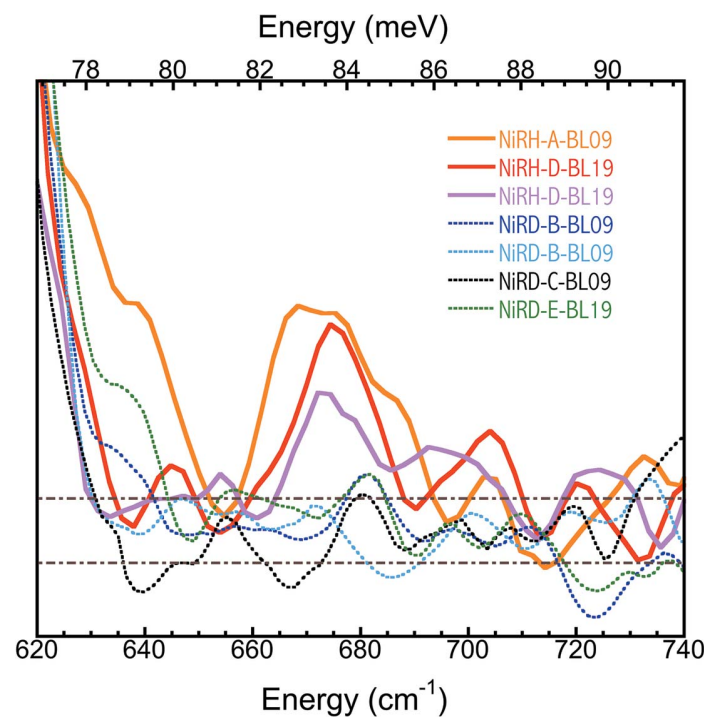

Figure 7

PVDOS for three NiR-H (solid curves) and four NiR-D (dotted curves). In the legends, the front letters indicate sample type (NiR-H or NiR-D), the middle letter marks the beam time sequence, and the last letters/ numbers record the beamline at which the particular measurement was made.

in their protonation states but they are all Ni-R. The NiR-H (blue) sample comprised $84 \% \mathrm{Ni}-\mathrm{R} 1\left(v_{\mathrm{CO}}=1946 \mathrm{~cm}^{-1}\right), 16 \%$ $\mathrm{NiC}\left(\right.$ at $\left.1962 \mathrm{~cm}^{-1}\right)$ and a trace amount of $\mathrm{Ni}-\mathrm{R} 2\left(v_{\mathrm{CO}}=\right.$ $1933 \mathrm{~cm}^{-1}$ ). The NiR-D (red) comprised almost $100 \%$ Ni-R1.

(ii) NiR-H/D after NRVS measurements were also collected and checked with FTIR and both IR spectra [blue for NiR-H and red for NiR-D in Fig. 8(b)] show little change in comparison with those measured before sending for NRVS experiments (Fig. 8a), confirming the integrity of the samples for the whole NRVS measurement.

(iii) Immediately prior to a NRVS measurement, in situ NRVS measurement in a sample's Fe-S region was another

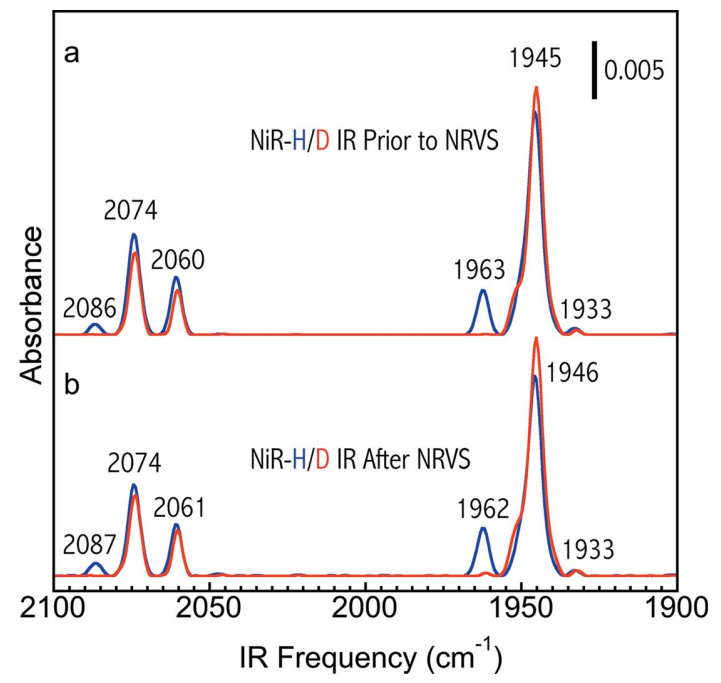

Figure 8

FTIR spectra for one pair of particular NiR-H (blue) and NiR-D (red) samples collected $(a)$ before sending to and $(b)$ after returning from the NRVS measurements.

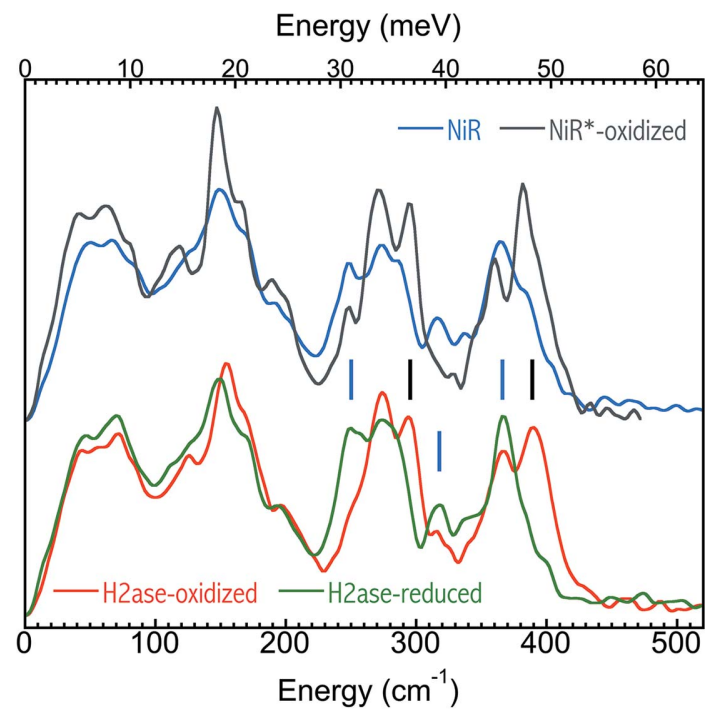

Figure 9

The first two-scan averaged NRVS spectra for a good Ni-R sample (light blue) and a bad (unexpectedly oxidized) $\mathrm{Ni}-\mathrm{R}$ sample versus the established NRVS spectra for the oxidized (red) and reduced (green) $D v \mathrm{MF} \mathrm{H}_{2}$ ase (Kamali et al., 2013).

way of carrying out a last-minute check, as shown in Fig. 9. For example, the light blue curve shows one example of many good Ni-R samples measured in this study (e.g. for those used in Fig. 7), while the black curve shows one bad (unexpectedly oxidized) 'Ni-R' sample. The green and red spectra are the established NRVS for the oxidized and reduced $D v \mathrm{MF} \mathrm{H}_{2}$ ase (Kamali et al., 2013). Although such an identified reduced state may not be a Ni-R, the real control over the samples' integrity is via the FTIR measurements prior to and following the NRVS experiments, as shown in Fig. 8. This in situ examination was used only as a handy check that the sample was not oxidized (e.g. Fig. 9, black curve) before investing a long beam time on the sample.

There are a lot of features in the $\mathrm{Fe}-\mathrm{S}$ region which can be used to characterize the oxidation states of $\mathrm{NiFe}_{2} \mathrm{H}_{2}$ ase, including the peaks between 340 and $460 \mathrm{~cm}^{-1}$ (Kamali et al., 2013). At BL09XU (Fig. 4, column 4), a hypothetical $4 \mathrm{mM}$ $D v \mathrm{MF} \mathrm{H}_{2}$ ase sample will have 3-6 cts/s in its $\mathrm{Fe}-\mathrm{S}$ region, and three regular $5 \mathrm{~s} / \mathrm{p}$ scans will produce $45-90$ total cts or a statistical $\mathrm{S} / \mathrm{N}$ of $6.7-9.5$. As the dark current is much smaller in comparison with the $\mathrm{Fe}-\mathrm{S}$ signal cts/s, the statistical $\mathrm{S} / \mathrm{N}$ is close to the real $\mathrm{S} / \mathrm{N}$. Then a $\mathrm{S} / \mathrm{N}$ of $7-9$ should be sufficient to resolve the samples' oxidation states. At BL19LXU, in principle, one scan is enough, but we usually took two $3 \mathrm{~s} / \mathrm{p}$ scans in order to check the repeatability.

\subsection{Miscellaneous issues}

We noticed that the low dark cts/s of the APD array (i.e. $0.03 \mathrm{cts} / \mathrm{s}$ ) stays the same at BL19LXU, which has a higher beam intensity than BL09XU. If this dark-current level increases at BL19LXU, the increased cts/s will become less meaningful. We also noticed that the higher beam intensity at BL19LXU does not lead to higher sample temperatures (Wang et al., 2012) during the NRVS measurement. This again 
illustrates the conclusion in our previous publication, which suggested that the hike in the samples' temperatures in comparison with the sample base is mainly due to thermal radiation from the room-temperature window near the samples rather than from the X-ray irradiation (Wang et al., 2012).

As the HRM is inside the same hutch as the NRVS measurement chamber, entering the hutch can disturb the hutch temperature and the performance of the HRM. A sample change or other regular operation, which lasts $\sim 30 \mathrm{~min}$, will lead to a system recovery time of about $2 \mathrm{~h}$. In the case of an emergency entry for $\sim 1 \mathrm{~min}$, the system can be recovered in about 20-30 min. As mentioned earlier, the energy scale can be calibrated either normally or with a quickswitch calibration procedure (Wang et al., 2013). For concentrated NiR-H/D samples, the Fe-S peak at $365 \mathrm{~cm}^{-1}$ (Fig. 9) can also be used as a calibration reference because of its high signal level.

\subsection{Looking for $\mathrm{Fe}-\mathrm{H} / \mathrm{D}$ stretching modes}

The Fe-H or Fe-D stretching modes will have no overlaps with any possible NRVS peaks in the same regions and will allow a straightforward experimental identification of the hydride. However, in reference to the model complexes and DFT calculations (Ogata, Kramer et al., 2015), Fe-D has $1 / 5$ of the intensity of $\mathrm{Ni}-\mathrm{H}-\mathrm{Fe}$ (see Fig. 5) while $\mathrm{Fe}-\mathrm{H}$ has $1 / 15$ of that of $\mathrm{Ni}-\mathrm{H}-\mathrm{Fe}$ (not shown in Fig. 5), presenting further challenges. Under the current experimental conditions, all these peaks are still not observable unless significant improvements in beam intensity, sample concentration and/or measurement solid angles are made. Different improvements and tests are underway. From the NiDFe complex, the $711 \mathrm{~cm}^{-1} \mathrm{Ni}-\mathrm{D}$ stretching bending peak (mixed with $\mathrm{Fe}$ ) has about the same intensity as $\mathrm{Ni}-\mathrm{H}-\mathrm{Fe}$. However, it could be mixed with $\mathrm{Fe}-\mathrm{CO}$ and is not observable in Ni-R (Ogata, Kramer et al., 2015).

\section{Conclusions}

This publication has presented the strenuous experimental journey to discover the first spectroscopic evidence for the existence of a bridging hydride in a [NiFe] $\mathrm{H}_{2}$ ase's $\mathrm{Ni}-\mathrm{R}$. The observed weak $\mathrm{Ni}-\mathrm{H}-\mathrm{Fe}$ wagging mode has $27-29$ parts per million in intensity in comparison with the nuclear resonance peak, or $\sim 0.8 \%$ in comparison with a Fe-S feature. Improved sample concentration, increased photon flux and ultra-low noise level in the APD detectors all set the foundation for a possible NRVS measurement of the weak Ni-H-Fe. The decision and insistence on searching in the then unlikely energy region of $620-720 \mathrm{~cm}^{-1}$ was the key step towards successful observation of the $\mathrm{Ni}-\mathrm{H}-\mathrm{Fe}$ at $675 \mathrm{~cm}^{-1}$. The existence/non-existence of the $675 \mathrm{~cm}^{-1}$ peak for NiR-H/NiR$\mathrm{D}$ identified the peak as a Fe-H-related feature experimentally. The Ni-H-Fe feature at $675 \mathrm{~cm}^{-1}$ provided a critical observed reference for DFT calculations and thus served as a key in the DFT determination of the Ni-R structures (Ogata,
Kramer et al., 2015). The experimental science discussed here will also have a much broader impact beyond $\mathrm{Ni}-\mathrm{R}$ and even beyond [NiFe] $\mathrm{H}_{2}$ ases. It will be of interest to other scientists who use synchrotron radiation for measuring dilute samples and/or weak spectroscopic features in general.

\section{Acknowledgements}

This work was funded by NIH (GM-65440) and DOE Office of Biological and Environmental Research (both to Professor Stephen P. Cramer at UC Davis). We also thank Professor Cramer for his overall support to this research. The work was also supported by BMBF (03SF0355C), EU/Energy Network project SOLAR-H2 (FP7 contract 212508), DFG-funded Cluster of Excellence RESOLV (EXC1069) and Max Planck Society (HO and WL). Use of SPring- 8 is supported by JASRI (via proposals 2012A0032-2013B0032 and 2014B1032) and RIKEN (via proposals 20120107 and 20130022).

\section{References}

Amara, P., Volbeda, A., Fontecilla-Camps, J. C. \& Field, M. J. (1999). J. Am. Chem. Soc. 121, 4468-4477.

Armstrong, F. A. (2009). Photosynth. Res. 102, 541-550.

Armstrong, F. A., Belsey, N. A., Cracknell, J. A., Goldet, G., Parkin, A., Reisner, E., Vincent, K. A. \& Wait, A. F. (2009). Chem. Soc. Rev. 38, 36-51.

Barilone, J. L., Ogata, H., Lubitz, W. \& van Gastel, M. (2015). Phys. Chem. Chem. Phys. 17, 16204-16212.

Barton, B. E., Whaley, C. M., Rauchfuss, T. B. \& Gray, D. L. (2009). J. Am. Chem. Soc. 131, 6942-6943.

Bergmann, U., Sturhahn, W., Linn, D. E., Jenney, F. E., Adams, M. W. W., Rupnik, K., Hales, B. J., Alp, E. E., Mayse, A. \& Cramer, S. P. (2003). J. Am. Chem. Soc. 125, 4016-4017.

Brecht, M., van Gastel, M., Buhrke, T., Friedrich, B. \& Lubitz, W. (2003). J. Am. Chem. Soc. 125, 13075-13083.

Cammack, R., Frey, M. \& Robson, R. (2001). Editors. Hydrogen as a Fuel: Learning from Nature. New York: Taylor \& Francis.

Cramer, S. P., Xiao, Y., Wang, H., Guo, Y. \& Smith, M. C. (2007). Hyperfine Interact. 170, 47-54.

Crossland, J. L., Young, D. M., Zakharov, L. N. \& Tyler, D. R. (2009). Dalton Trans. 2009, 9253-9259.

De Lacey, A. L., Fernández, V. M., Rousset, M. \& Cammack, R. (2007). Chem. Rev. 107, 4304-4330.

Do, L. H., Wang, H., Tinberg, C. E., Dowty, E., Yoda, Y., Cramer, S. P. \& Lippard, S. J. (2011). Chem. Commun. 47, 10945-10947.

Dole, F., Fournel, A., Magro, V., Hatchikian, E. C., Bertrand, P. \& Guigliarelli, B. (1997). Biochemistry, 36, 7847-7854.

Dong, W., He, P., Wang, J., Zhou, Z. \& Wang, H. (2013). Infrared Phys. Technol. 56, 51-56.

Evans, R. M., Parkin, A., Roessler, M. M., Murphy, B. J., Adamson, H., Lukey, M. J., Sargent, F., Volbeda, A., Fontecilla-Camps, J. C. \& Armstrong, F. A. (2013). J. Am. Chem. Soc. 135, 2694-2707.

Foerster, S., Stein, M., Brecht, M., Ogata, H., Higuchi, Y. \& Lubitz, W. (2003). J. Am. Chem. Soc. 125, 83-93.

Fontecilla-Camps, J. C., Volbeda, A., Cavazza, C. \& Nicolet, Y. (2007). Chem. Rev. 107, 4273-4303.

Fritsch, J., Lenz, O. \& Friedrich, B. (2013). Nat. Rev. Microbiol. 11, 106-114.

Gastel, M. van, Stein, M., Brecht, M., Schröder, O., Lendzian, F., Bittl, R., Ogata, H., Higuchi, Y. \& Lubitz, W. (2005). J. Biol. Inorg. Chem., 11, 41-51.

Goto, S., Ishikawa, T., Kitamura, H. \& Takahashi, S. (2000). SPring-8 Annual Report pp. 30-35. SPring-8, Hyogo, Japan. 
Gu, W., Jacquamet, L., Patil, D. S., Wang, H.-X., Evans, D. J., Smith, M. C., Millar, M., Koch, S., Eichhorn, D. M., Latimer, M. \& Cramer, S. P. (2003). J. Inorg. Biochem. 93, 41-51.

Guiral, M., Tron, P., Belle, V., Aubert, C., Leger, C., Guigliarelli, B. \& Giudici-Orticoni, M. (2006). Int. J. Hydrogen Energy, 31, 14241431.

Hara, T., Yabashi, M., Tanaka, T., Bizen, T., Goto, S., Marechal, X. M., Seike, T., Tamasaku, K., Ishikawa, T. \& Kitamura, H. (2002). Rev. Sci. Instrum. 73, 1125-1128.

Heinekey, D. M. (2009). J. Organomet. Chem. 694, 2671-2680.

Inada, T., Namba, T., Asai, S., Kobayashi, T., Tanaka, Y., Tamasaku, K., Sawada, K. \& Ishikawa, T. (2013). Phys. Lett. B, 722, 301304.

Jayapal, P., Robinson, D., Sundararajan, M., Hillier, I. H. \& McDouall, J. J. W. (2008). Phys. Chem. Chem. Phys. 10, 1734-1738.

Jugder, B. E., Welch, J., Aguey-Zinsou, K. F. \& Marquis, C. P. (2013). RSC Adv. 3, 8142-8159.

Kamali, S., Wang, H., Mitra, D., Ogata, H., Lubitz, W., Manor, B. C., Rauchfuss, T. B., Byrne, D., Bonnefoy, V., Jenney, F. E. Jr, Adams, M. W. W., Yoda, Y., Alp, E., Zhao, J. \& Cramer, S. P. (2013). Angew. Chem. Int. Ed. 52, 724-728.

Kim, J. Y. H. \& Cha, H. J. (2013). Korean J. Chem. Eng. 30, 1-10.

Lauterbach, L., Wang, H., Horch, M., Gee, L. B., Yoda, Y., Tanaka, Y., Zebger, I., Lenz, O. \& Cramer, S. P. (2015). Chem. Sci. 6, 1055-1060.

Lubitz, W. \& Ogata, H. (2013). Encyclopedia of Biological Chemistry, edited by W. J. Lennarz and M. D. Lane, pp. 562-567. London: Academic Press.

Lubitz, W., Ogata, H., Rüdiger, O. \& Reijerse, E. (2014). Chem. Rev. 114, 4081-4148.

Matsumoto, T., Kim, K., Nakai, H., Hibino, T. \& Ogo, S. (2013). Chem. Cat. Chem. 5, 1368-1373.

Mertens, R. \& Liese, A. (2004). Curr. Opin. Biotechnol. 15, 343-348.

Ogata, H., Hirota, S., Nakahara, A., Komori, H., Shibata, N., Kato, T., Kano, K. \& Higuchi, Y. (2005). Structure, 13, 1635-1642.

Ogata, H., Kramer, T., Wang, H., Schilter, D., Pelmenschikov, V., van Gastel, M., Neese, F., Rauchfuss, T. B., Gee, L. B., Scott, A. D., Yoda, Y., Tanaka, Y., Lubitz, W. \& Cramer, S. P. (2015). Nat. Commun. 6, 7890.

Ogata, H., Nishikawa, K. \& Lubitz, W. (2015). Nature, 520, 571-574. Pelmenschikov, V., Guo, Y., Wang, H., Cramer, S. P. \& Case, D. A. (2011). Faraday Discuss. 148, 409-420.

Schilter, D., Nilges, M. J., Chakrabarti, M., Lindahl, P. A., Rauchfuss, T. B. \& Stein, M. (2012). Inorg. Chem. 51, 2338-2348.

Seto, M., Yoda, Y., Kikuta, S., Zhang, X. W. \& Ando, M. (1995). Phys. Rev. Lett. 74, 3828-3831.

Shafaat, H. S., Rüdiger, O., Ogata, H. \& Lubitz, W. (2013). Biochim. Biophys. Acta, 1827, 986-1002.

Shafaat, H. S., Weber, K., Petrenko, T., Neese, F. \& Lubitz, W. (2012). Inorg. Chem. 51, 11787-11797.

Simmons, T. R. \& Artero, V. (2013). Angew. Chem. Int. Ed. 52, 61436145.
Smith, M. C., Xiao, Y. M., Wang, H. X., George, S. J., Coucouvanis, D., Koutmos, M., Sturhahn, W., Alp, E. E., Zhao, J. Y. \& Cramer, S. P. (2005). Inorg. Chem. 44, 5562-5570.

Sturhahn, W., Toellner, T. S., Alp, E. E., Zhang, X., Ando, M., Yoda, Y., Kikuta, S., Seto, M., Kimball, C. W. \& Dabrowski, B. (1995). Phys. Rev. Lett. 74, 3832-3835.

Takahashi, S., Aoyagi, H., Mochizuki, T., Oura, M., Sakurai, Y., Watanabe, A. \& Kitamura, H. (2001). Nucl. Instrum. Methods Phys. Res. A, 467-468, 758-761.

Tanaka, Y., Uozaki, Y., Nozaki, K., Ito, K., Yamasaki, K., Terauchi, H., Takahashi, I. \& Ishikawa, T. (2011). J. Phys. Conf. Ser. 278, 012018.

Tard, C. \& Pickett, C. J. (2009). Chem. Rev. 109, 2245-2274.

Tinberg, C. E., Tonzetich, Z. J., Wang, H., Do, L. H., Yoda, Y., Cramer, S. P. \& Lippard, S. J. (2010). J. Am. Chem. Soc. 132, 18168 18176.

Volbeda, A., Martin, L., Barbier, E., Gutiérrez-Sanz, O., De Lacey, A., Liebgott, P., Dementin, S., Rousset, M. \& Fontecilla-Camps, J. (2015). J. Biol. Inorg. Chem. 20, 11-22.

Wang, H., Alp, E., Yoda, Y. \& Cramer, S. (2014). Methods in Molcular Cell Biology, Vol. 1122, Metalloproteins, edited by J. C. FontecillaCamps and Y. Nicolet, pp. 125-137. New Jersey: Humana Press.

Wang, H., Patil, D. S., Gu, W., Jacquamet, L., Friedrich, S., Funk, T. \& Cramer, S. P. (2001). J. Electron Spectrosc. Relat. Phenom. 114-116, 855-863.

Wang, H., Patil, D. S., Ralston, C. Y., Bryant, C. \& Cramer, S. P. (2001). J. Electron Spectrosc. Relat. Phenom. 114-116, 865-871.

Wang, H. X., Ralston, C. Y., Patil, D. S., Jones, R. M., Gu, W., Verhagen, M., Adams, M., Ge, P., Riordan, C., Marganian, C. A., Mascharak, P., Kovacs, J., Miller, C. G., Collins, T. J., Brooker, S., Croucher, P. D., Wang, K., Stiefel, E. I. \& Cramer, S. P. (2000). J. Am. Chem. Soc. 122, 10544-10552.

Wang, H., Yoda, Y., Dong, W. \& Huang, S. D. (2013). J. Synchrotron Rad. 20, 683-690.

Wang, H., Yoda, Y., Kamali, S., Zhou, Z.-H. \& Cramer, S. P. (2012). J. Synchrotron Rad. 19, 257-263.

Xiao, Y. M., Wang, H. X., George, S. J., Smith, M. C., Adams, M. W. W., Jenney, F. E., Sturhahn, W., Alp, E. E., Zhao, J. O., Yoda, Y., Dey, A., Solomon, E. I. \& Cramer, S. P. (2005). J. Am. Chem. Soc. 127, 14596-14606.

Yabashi, M., Mochizuki, T., Yamazaki, H., Goto, S., Ohashi, H., Takeshita, K., Ohata, T., Matsushita, T., Tamasaku, K., Tanaka, Y. \& Ishikawa, T. (2001). Nucl. Instrum. Methods Phys. Res. A, 467468, 678-681.

Yang, J. Y., Bullock, M., DuBois, M. R. \& DuBois, D. L. (2011). MRS Bull. 36, 39-47.

Yoda, Y., Imai, Y., Kobayashi, H., Goto, S., Takeshita, K. \& Seto, M. (2012). Nucl. Instrum. Methods Phys. Res. A, 206, 83.

Yoda, Y., Yabashi, M., Izumi, K., Zhang, X. W., Kishimoto, S., Kitao, S., Seto, M., Mitsui, T., Harami, T., Imai, Y. \& Kikuta, S. (2001). Nucl. Instrum. Methods Phys. Res. A, 467-468, 715-718. 